\title{
Exploration and Corrective Measures of Greenhouse Gas Emission from Fossil Fuel Power Stations for Bangladesh
}

\author{
Ashish Kumar Karmaker ${ }^{1}$, Md. Mijanur Rahman ${ }^{1}$, Md. Alamgir Hossain ${ }^{1,2}$, Md. Raju Ahmed ${ }^{1}$ \\ ${ }^{1}$ Department of Electrical and Electronic Engineering, Dhaka University of Engineering \& Technology, Gazipur \\ ${ }^{2}$ School of Engineering and Information Technology, University of New South Wales, Canberra, Australia
}

\begin{abstract}
Greenhouse gas emission is increasing alarmingly due to bulk electricity generation from fossil fuel such as coal, gas and oil with its limited stock. While researchers are struggling to minimize the emission using suitable mitigation techniques including renewable energy sources, the Government of Bangladesh is implementing several Coal based power plants. This paper presents mathematical model of parameters related to Greenhouse gas emission and demonstrates its emission rates resulting from various fuels used in Bangladeshi power plants. The Greenhouse gas emission from the existing fossil fuel power plants using HOMER (Hybrid Optimization of Multiple Energy Resources) software is analyzed in this research. The result shows that power plants of coal, diesel and natural gas emit $0.90 \mathrm{~kg}, 0.76 \mathrm{~kg}$ and 0.566 $\mathrm{kg}$ of $\mathrm{CO}_{2}$ per $\mathrm{kWh}$, respectively. Furthermore, several Greenhouse gas mitigating procedures are proposed for fossil fuel-based power generating stations.
\end{abstract}

Keywords: Fossil fuel; Greenhouse gas emission; $\mathrm{CO}_{2}$ emission; HOMER

\section{Introduction}

The fastest-growing population and industrialization lead to huge electricity demand in the entire world with a significant challenge in reducing Greenhouse gas (GHG) emission. Researchers around the world are concerned about reducing emission corresponding to electricity generation. Limited resources of fossil fuel like coal, natural gas and diesel are being used in the majority of power generating stations in the world. The use of fossil fuel resources in power generation is increasing global warming potential, intensifying sea level and destroying the climate forms. Despite these drawbacks, the total capacity of fossil fuel-based power plants around the world is increasing and reached up to $3500 \mathrm{GW}$ by 2016 leading to threaten to the environment [Amin et. al. 2019].

Among other fossil fuels, coal is prominent for production of several harmful greenhouse gases including $\mathrm{CO}_{2}, \mathrm{SO}_{2}, \mathrm{NO}_{\mathrm{x}}$, and other particulate matters. Research exhibited that combustion of coal is greatly responsible for a large amount of GHG emission which further escalates global warming potential [Smith et. al. 2019]. Major portions of the coal power plants are operated with older technologies with low quality coals which also increase $\mathrm{CO}_{2}$ emission [Eyre et. al. 2018]. Different technologies are recognized to lessen $\mathrm{CO}_{2}$ emission in a coal-fired power plant. Use of carbon capture \& storage technologies in conventional power station reduces up to $84 \%$ GHG emission compared to sub-critical coal based power plant, whereas integrated gasification coal combustion helps to reduce up to $160 \mathrm{~g} / \mathrm{kWh}$ [Baky et. al. 2017]. Another study performed in the perspectives of Bangladesh reveals that the major barriers to coal based 
power generation include coal locations, legal policy, technological improvement, health, safety, and environmental issues [Zaman et. al. 2018].

Another notable fossil fuel is natural gas used for power generation. Rapid fuel switching from coal to natural gas lay down the GHG emission by $6 \%$ in Great Britain as showed in a study [Wilson et. al. 2018]. On the other hand, electricity generation based on conventional Liquefied Natural Gas (LNG) burned in an open cycle gas turbine plant emits $38 \%$ less GHG over its life cycle compared to black coal burned in a sub-critical plant in Australia [Weldu et. al. 2017]. GHG emission from natural gas based power plant is two times lesser than imported coal-fired power plant in India [Cristian Dinca et. al. 2008]. However, natural gas resources are declining worldwide with their involvement in various applications, such as cooking, transportation sector and so on. Thus, the researchers are looking for the substitution of natural gas for integrating in bulk amount of power generation [Gilbert et. al. 2018].

Petroleum oil such as diesel, heavy fuel oil, liquefied petroleum and gasoline based power generation is facing difficulties with high cost and corresponding GHG emission to the atmosphere. An analysis shows using time varying carbon intensity exhibits coal (subbituminous), natural gas and diesel based generation yields $0.87 \mathrm{~kg}, 0.42 \mathrm{~kg}$ and $0.63 \mathrm{~kg}$ of $\mathrm{CO}_{2}$ per kWh, respectively, in the perspective of New Zealand [Khan et.al. 2018]. A comparative Life Cycle Assessment (LCA) of GHG emission executed in Macau city, China reports that electricity generation from natural gas, heavy oil \& municipal solid waste incineration harvests $0.42 \mathrm{~kg}, 0.7 \mathrm{~kg}$ and $0.95 \mathrm{~kg}$ of $\mathrm{CO}_{2}$ per $\mathrm{kWh}$, respectively [Song et. al.2017]. Another study presented that organic waste composting techniques promotes environmental sustainability by limiting GHG emission and provides fertilizer for the agricultural sector [Kamyab et. al. 2015].

Developed countries are focused heavily on lowering carbon program in the power sector by lessening the use of fossil fuel. In the case of developing countries, the use of fossil fuel in power generation is increasing where no carbon mitigation technologies are employed. Therefore, the chance of GHG emission in those power plants is more and causing great harm to the environmental sustainability [Xiang Yu et. al. 2018]. Like other developing countries, Bangladesh is also experiencing huge GHG emission problem from fossil fuel power stations. Although conventional fossil fuel used in power plants requires low cost, plant efficiency is getting decreased due to ageing effects. As a consequence more GHG emission is occurring by the existing fossil fuel power plants in Bangladesh. To achieve sustainable development in the power sector, the government has a plan towards net-zero carbon emission policy 2041[Hoque et. al. 2019]. However, there is no clear strategy against reducing GHG emissions from fossil fuels.

On the other hand, globally fossil fuel based power plant is getting decreased owing to the inadequacy of fossil fuel resources with environmental pollution [Kaberger et. al. 2018]. Hence, environmentalists are discouraging to establish such type of fossil fuel power plants in the worldwide [Zhou et. al. 2019]. However, in Bangladesh, this type of power plant construction is rising. Additionally, a sudden increase in electric vehicles in Bangladesh involves huge electricity consumption which further increases the GHG emission indirectly 
[Karmaker et. al. 2018]. In this context, it is essential to determine the GHG emission from such power plant in Bangladesh to overcome this problem by taking proper mitigating strategies.

As it is known, Bangladesh is ranked the $10^{\text {th }}$ largest densely populated country in the world and is rapidly flourishing in socio-economic and technological advancement [Rahman et. al. 2019]. For making such development to a sustainable one, electricity plays a vital role. With the rapid proliferation of electricity demand, the power plant infrastructure with its capacity is also expanding. Total installed capacity of electricity generation is increased to $15,519 \mathrm{MW}$ by $30^{\text {th }}$ December, 2018 where energy generation can be divided as natural gas $(64.52 \%)$, coal $(1.81 \%)$, diesel $(6.36 \%)$, furnace oil $(20.87 \%)$, hydro (1.66\%) $(1.66 \%)$ and renewable energy $(0.02 \%)$ [Amin et. al. 2019]. However, using existing energy generation capacity, it is quite impossible to meet the emerging demand of electricity and the GHG emission from corresponding power generation is very perilous [Sharif et. al. 2018].

Conversely, the huge potentiality of renewable resources, such as solar, biomass and wind, based electricity generation reduces GHG emission significantly in Bangladesh which is demonstrated in various studies [Das et. al. 2018; Rashid et.al. 2017]. In another research, it is presented that waste to energy (WTE) technology can be a potential solution for subsiding GHG emissions in Bangladesh to build a sustainable environment [Islam et. al. 2017]. An analysis revealed that it increases the system stability with declining $\mathrm{CO}_{2}$ emission up to 497,78,600 tons by 2022 when Egyptian power network integrated with $20 \%$ renewable energy [Nassar et. al. 2018]. Besides, the use of available renewable resources can meet the electricity demand as well as maintain the global warming potential within a safe limit [Owusu et. al. 2016]. Although it is described in the contemporary researches that renewable energy utilization decreases GHG emission noticeably, it is not practiced in the power generating sector of Bangladesh effectively due to lack of policies, awareness and improved technologies regarding mitigation of $\mathrm{GHG}$ emission.

While there are a number of research articles present in the literature, for example several carbon emission reasons from NewZealand electricity grid [Walmsley et. al. 2018], assessing carbon footprint from Iranian power network [Dalir et. al. 2018], and research to reduce $\mathrm{CO}_{2}$ in Brazil, Europe, and Japan [Audoly et. al. 2018], to the best of authors' knowledge, no research articles on the analysis of GHG emission from fossil fuel power plant and the mitigating strategies in details are published, especially from Bangladeshi context. Therefore, this paper explores and proposes effective mitigating strategies of GHG emission based on fossil fuel power system. The main contributions of the study are:-

- To analyze the GHG emission with respect to different fuels, technology and rating of the generating stations

- To develop a mathematical model to measure the GHG emission from different power plants

- To demonstrate the GHG emission from fossil fuel power generating stations using HOMER software and 
- To propose several GHG mitigating procedures for conventional power systems in Bangladesh.

The construct of the paper is as follows. Section 2.0 illustrates the methods where analytical framework is demonstrated. In addition to this, mathematical modeling of the GHG emission from power station involving several parameters is presented. Section 3.0 presents the results and discussion whereas section 4.0 shows the implications for mitigating GHG emission. Finally, section 5.0 concludes with the findings and future research directions.

\section{Methods}

The methods section comprises two subsections including analytical framework and mathematical model. Analytical framework mainly describes the whole process where the exploration of GHG emission is conducted in this research. Moreover, the mathematical modeling section analyzes the expression for GHG emission.

\subsection{Analytical framework}

In order to explore the GHG emission from the existing fossil fuel power stations in Bangladesh, the primary data related to energy consumption, demand along with the fuel used is collected from the online sites of the power sector. Also, the data corresponding to fuel consumption and GHG emission is obtained from the field visit of the different power stations in Bangladesh. For achieving data, authors have visited Ghorashal Power Station Company Limited, Ashuganj Power Station Company Limited, Rural Power Company Limited, Northwest Power Generation company Limited and also the Coal Power Generation Company Limited which is under construction now. Besides, the contemporary researches allied with the power plant emission provide the secondary data. The analytical framework for the exploration of the GHG emission is shown in Fig.1.

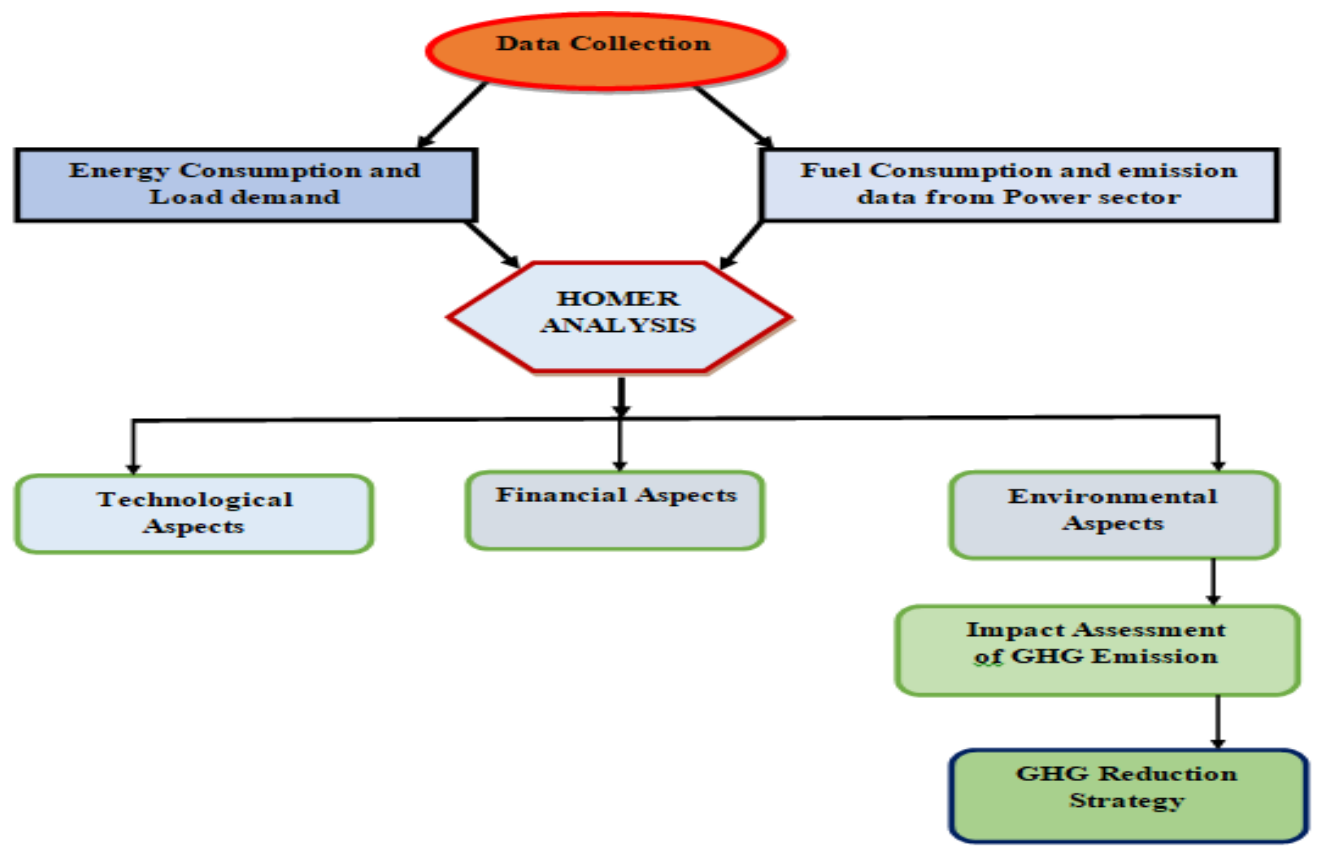

Fig.1: Analytical framework for the research 
In this research, the data (i.e. energy generation, load demand, fuel consumption, technology used, and so on) acquired from different power stations are used in HOMER software. HOMER stands for Hybrid Optimization of Multiple Energy Resources which is a software developed by the National Renewable Energy Laboratory in the United States. It is used for designing and evaluating the technical, financial and environmental parameters of fossil fuel and renewable based generation. In this paper, the environmental impacts of the fossil fuel power station are evaluated using HOMER software. Mathematical analysis of the GHG emission is illustrated using the data which are collected from HOMER analysis \& existing power plant in Bangladesh. Finally, several policies for minimizing GHG emission from fossil fuel power plant are proposed in this paper.

\subsection{Mathematical Model}

Electricity generation plant often plays a vital role in producing GHG emission. The amount of GHG emission is thus needed to be calculated precisely. In a GHG analysis model, activity rate and emission factor are the two major components. These two factors are influenced by energy consumption, type of fuel and the technology used in the plant. Emission factor, a constant, represents the amount of pollutant emancipate to the atmosphere. It is generally expressed as amount of pollutant divided by a unit weight. The general equation for emissions estimation is given in equation (1):

$$
E=\lambda * E f *\left(\frac{1-E r}{100}\right)
$$

where $E$ is the total emissions; $\lambda$ is the activity rate; $E_{f}$ is the emission factor and $E r$ is the overall emission reduction efficiency [Hondo et. al. 2005]. $\mathrm{CO}_{2}$ is the paramount part of GHG emission. The $\mathrm{CO}_{2}$ emission can be calculated using the formula given below;

$$
E_{F}=\frac{\sum_{i} F C * N C V * E F_{C O_{2}}}{E_{G}}
$$

where $F C$ is the fuel consumption for all units of power generation, $N C V$ is net calorific value and $E F_{C O 2}$ is $\mathrm{CO}_{2}$ emission factor and $E_{G}$ is the generation of energy supplied to the grid [Board C.E. 2009].The total energy generation supplied to grid can be calculated as equation (3):

$$
E_{G}=\frac{\sum_{i} F C^{*} N C V^{*} \eta_{e}}{3.6}
$$

where $\eta_{e}$ is the energy conversion efficiency. If the $E_{c a p}$ is the net capacity of the plant, $P L F$ is the plant load factor, then in case of off-grid power plant the $E_{G}$ can be expressed as follows [Board C.E. 2009]:

$$
E_{G}=E_{c a p} * P L F * 8760
$$


GHG emission depends upon different factors i.e. activity rate, energy use, technology used and so on [Tan et. al. 2017]. Thus it can be expressed as the function of these parameters in equation (5):

$$
E=f\left(x_{1}, x_{2}, x_{3} \ldots \ldots, x_{n}\right)
$$

where $X_{1}, X_{2}, X_{3}, \ldots \ldots, X_{n}$ are the factors influencing GHG emission from power station and $E$ is the total GHG emission. Due to uncertainty of the GHG emission from power plant, there always a difference is found between original value of the emission and the estimated value of GHG emission.

$$
E_{\text {ori }}=E_{\text {est }}+\varepsilon
$$

where $E_{o r i}, E_{\text {est }}$ and $\varepsilon$ are the original value, estimated or inventory value and unknown error of the GHG emission, respectively. Using Gaussian probability distribution, the probability of the error can be identified [Saikawa et. al. 2017].

$$
P(\varepsilon)=\frac{1}{2 \pi \sigma} \times \exp \left\{-\frac{(\mu-\varepsilon)^{2}}{2 \sigma^{2}}\right\}
$$

where $P(\varepsilon)$ is the probability of error value $\varepsilon ; \mu$ is mean error, also called a systematic error and

$\sigma$ is the standard deviation of errors, a measure of the uncertainty of the result.

\section{Results}

\subsection{GHG emission from power plant in Bangladesh}

Power plant in Bangladesh utilizes fossil fuel, such as natural gas, coal and oil, in a large-scale where renewable energy, i.e. hydro, solar, wind and biogas/biomass, are used in a small-scale. Fig. 2 displays the fuel based power plant capacity in Bangladesh. It illustrates natural gas, diesel and furnace oil are contributing maximum in power generation, whereas renewable energy resources are bottommost. Recently, coal based several projects are under construction which are Coal Power Generation Company Limited (1200 MW), Bangladesh- India Friendship Power Plant Company Limited (1320 MW) and Bangladesh- China Power Plant in Patuakhali (1320 MW) in Bangladesh. As the coal and natural gas based power generating stations are increasing rapidly, it is a crucial issue to analyze corresponding GHG emission for environmental sustainability. 


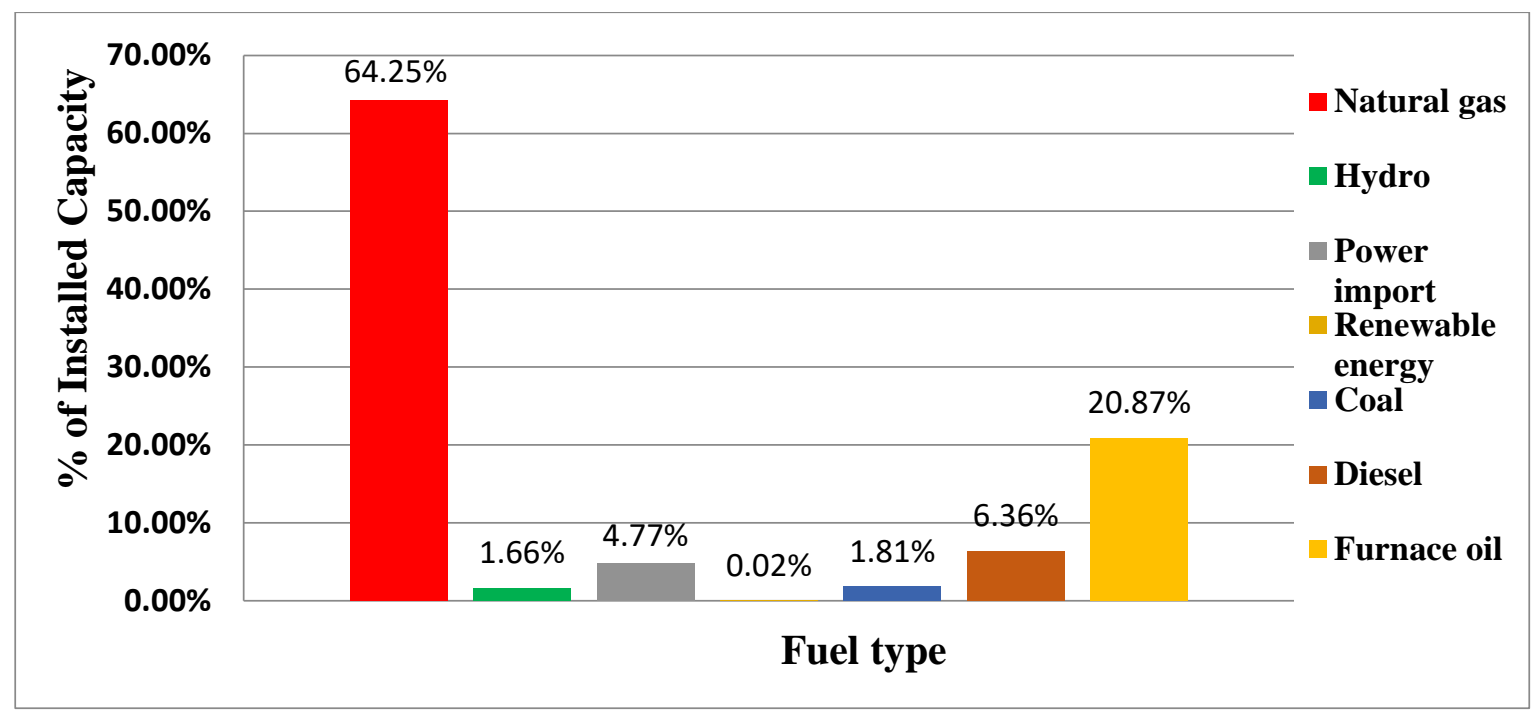

Fig. 2: Installed capacity of power plant in Bangladesh by fuel type [SREDA 2019]

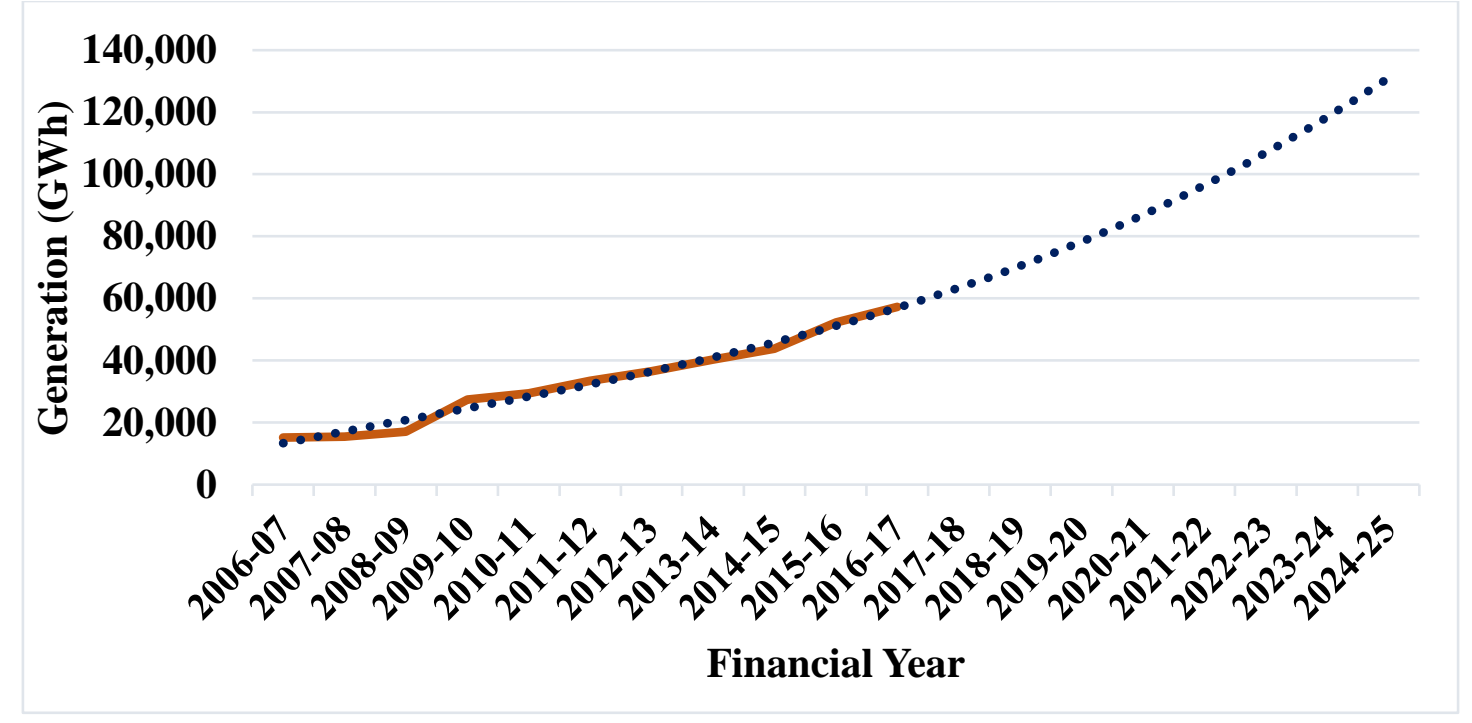

Fig. 3: Projection of power generation scenario per financial year

A prediction of $\mathrm{CO}_{2}$ emission is estimated considering the statistics of electricity generation taken from Bangladesh Power Development Board (BPDB) from 2006-2007 to 2024-2025 financial year. It is observed in Fig. 3 that extrapolation technique forecasts the energy generation at 2024-25 that will be 1,32,520 GWh. Rapid industrialization and improved life style of the people of Bangladesh leads to increasing the power demand that is facilitated by the use of electricity in charging the electric vehicles. Owing to such situation, GHG emission from the power generation is also increasing. A study discussed that, $\mathrm{CO}_{2}$ produced per $\mathrm{kWh}$ energy generation in Bangladesh is about $0.64 \mathrm{~kg}$ [Das et. al. 2017]. Using extrapolation, the value of $\mathrm{CO}_{2}$ emission due to energy generation will be $83,000 \mathrm{M}$ ton in the financial year of 2024-25, which is depicted in Fig. 4. 


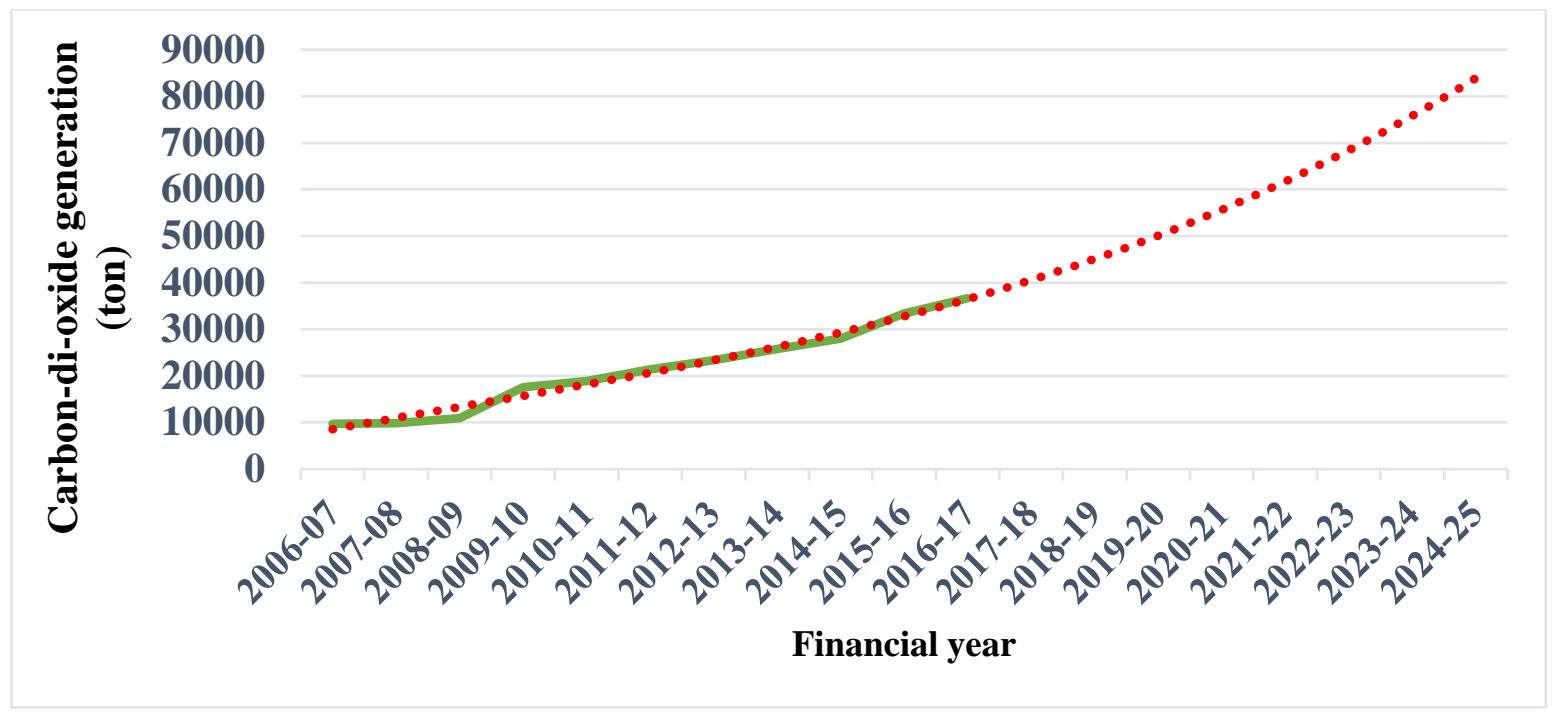

Fig. 4: Statistics of $\mathrm{CO}_{2}$ generation per financial year

As the extrapolation techniques results $\mathrm{GWh}$ and $\mathrm{CO}_{2}$ emission throughout the country in the year of 2024-25, it has some errors. The generation and corresponding GHG emission is actually quite different from the actual one due to the changes in fuel, the generation technological process, up gradation of the technology to be an optimized \& effective one. The quality of the fuel and their burning mechanism are being changed, thus extrapolation results may bring incorrect results. In other cases, the rapid industrialization raises the electricity demand which will be a threat to the GHG emission rendering environmental pollution. Therefore, to make the power system less dependable to fossil fuel for lower the rate of GHG emission, the results demonstrate possible outcome.

\subsection{GHG emission from HOMER analysis}

GHG emission is increasing with huge electricity demand in Bangladesh. In this case, it is an urgent issue for mitigating GHG emission coming from power generation. In this paper, first data, such as fuel type, technology used and generation capacity, are collected from the different power plants of Bangladesh. It is observed from the results using HOMER software simulation, almost all the power plant depends on the coal, natural gas and furnace oil/diesel with the significant amount of GHG emission.

Table [1]: GHG emission results (HOMER Analysis)

\begin{tabular}{|c|c|c|}
\hline Type of Fuel & Emission Parameter & Amount of Emission (kg/ kWh) \\
\hline \multirow{4}{*}{ Diesel } & $\mathrm{CO}_{2}$ & 0.760 \\
\cline { 2 - 3 } & $\mathrm{CO}$ & 0.005 \\
\cline { 2 - 3 } & Unburned Hydrocarbons & 0.00021 \\
\cline { 2 - 3 } & Particulate Matters & 0.0000293 \\
\cline { 2 - 3 } & $\mathrm{SO}_{2}$ & 0.0018 \\
\cline { 2 - 3 } & $\mathrm{NO}_{\mathbf{x}}$ & 0.00455 \\
\hline \multirow{4}{*}{ Coal } & $\mathrm{CO}_{2}$ & 0.90 \\
\cline { 2 - 3 } & $\mathrm{SO}_{2}$ & 0.00707 \\
\hline
\end{tabular}




\begin{tabular}{|c|c|c|}
\hline & $\mathrm{NO}_{\mathrm{x}}$ & 0.00428 \\
\hline \multirow{4}{*}{ Natural Gas } & $\mathrm{CO}_{2}$ & 0.566 \\
\cline { 2 - 3 } & $\mathrm{CO}$ & 0.00186 \\
\cline { 2 - 3 } & Particulate Matters & 0.0000525 \\
\cline { 2 - 3 } & $\mathrm{NO}_{\mathrm{x}}$ & 0.0039 \\
\hline
\end{tabular}

In Table [1], GHG emission from different fuels is shown. It can be seen that coal based power plant is the highest GHG emitter, and the diesel and natural gas have also a significant amount of GHG emission.

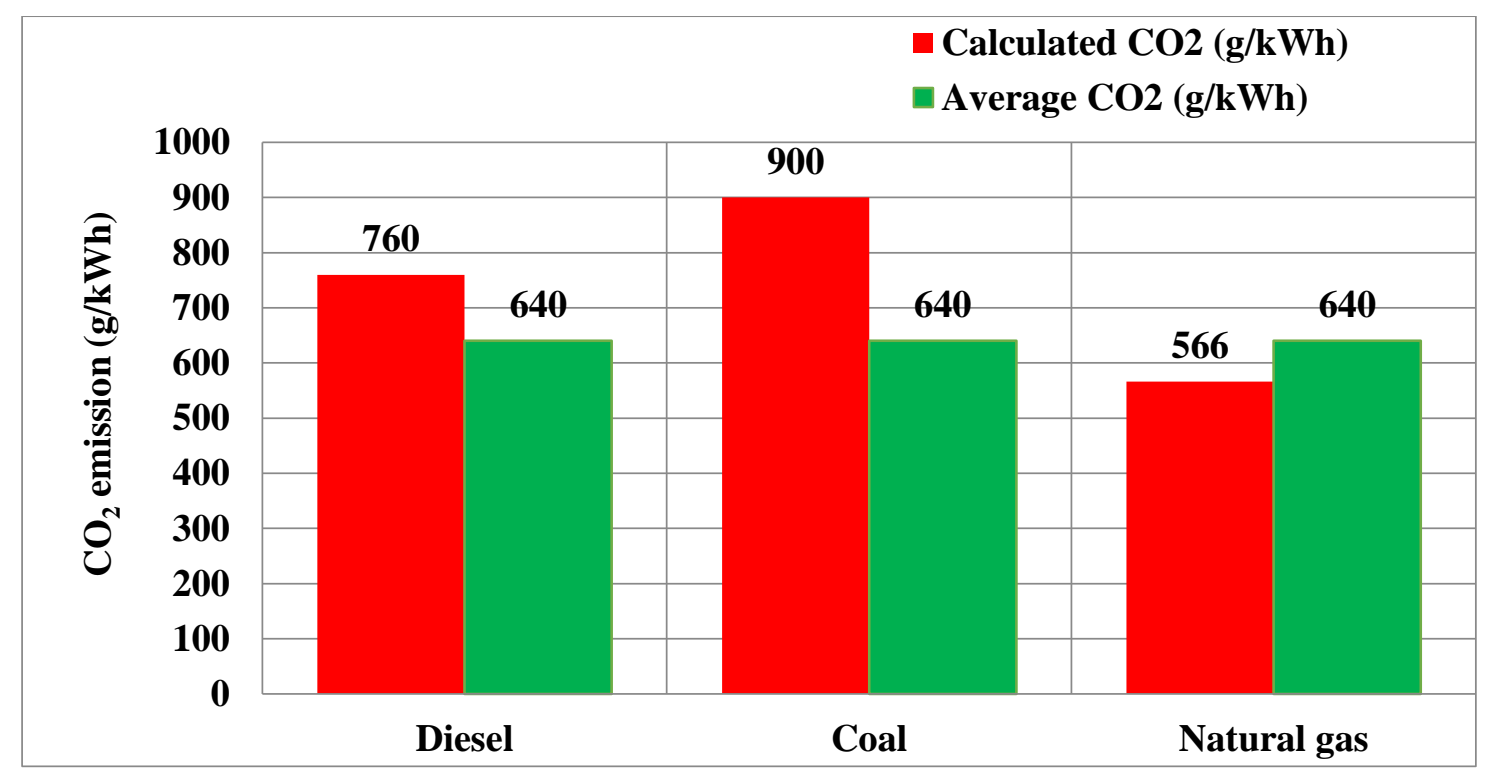

Fig. 5: Comparison of $\mathrm{CO}_{2}$ emission from various resources with average $\mathrm{CO}_{2}$ emission

Relative comparison between the average $\mathrm{CO}_{2}$ emission from fossil fuel based power station and the HOMER result are given in Fig. 5. It is seen from Fig. 5 that the calculated value of $\mathrm{CO}_{2}$ per $\mathrm{kWh}$ is less than the average value of $\mathrm{CO}_{2}$ per $\mathrm{kWh}$. It means that the actual emission differs from the usually used $\mathrm{CO}_{2}$ emission data.

Proliferation of the coal based power plant in Bangladesh is responsible for high mount of GHG emission to the environment. Use of coal having lower heating value increases the GHG emissions. The calorific value fluctuates for bituminous coal from $27,912 \mathrm{~kJ} / \mathrm{kg}$ to $34,890 \mathrm{~kJ} / \mathrm{kg}$ and for sub-bituminous coal from $19,300 \mathrm{~kJ} / \mathrm{kg}$ to $26,749 \mathrm{~kJ} / \mathrm{kg}$. In the case of Barapukuria and Khalishpur coal mine, the calorific value varied from $32,960 \mathrm{~kJ} / \mathrm{kg}$ to $29,099 \mathrm{~kJ} / \mathrm{kg}$ and from $34,225 \mathrm{~kJ} / \mathrm{kg}$ to $29,773 \mathrm{~kJ} / \mathrm{kg}$, respectively. On the other hand, in the case of imported coal, the gross calorific value varied from $20,818 \mathrm{~kJ} / \mathrm{kg}$ to $25,540 \mathrm{~kJ} / \mathrm{kg}$ [Kibria et. al. 2018]. The gross calorific value of Bangladeshi coal was higher than that of imported coal. It was also shown from the caloric value that-Bangladeshi coals are bituminous and imported coals are sub-bituminous [Bhuiyan et. al. 2014]. Thus, the use of bituminous coal lowers the chance of producing GHG emissions. As stated by Bangladesh Power Development Board (BPDB), at present diesel based generation becomes 2,889 MW. Thus, the large amount of power generation using diesel/furnace oil penetrates 
higher GHG emission where about $0.76 \mathrm{~kg}$ of $\mathrm{CO}_{2}$ produced per $\mathrm{kWh}$. Therefore, the use of diesel/oil in power generation needs higher heating value. Among diesel and coal fueled power plant, natural gas demonstrates the lowest GHG emission.

Table [2]: Error calculation

\begin{tabular}{|c|c|c|}
\hline Fuel Type & Average $\mathbf{C O}_{2}(\mathbf{g} / \mathbf{k W h})$ & \% Relative Error \\
\hline Diesel & \multirow{3}{*}{640} & 18.75 \\
\cline { 1 - 1 } \cline { 1 - 1 } Coal & & 40.625 \\
\cline { 1 - 1 } \cline { 3 - 3 } Natural gas & & -11.5625 \\
\hline
\end{tabular}

Table [2] indicates the relative error regarding $\mathrm{CO}_{2}$ emission per $\mathrm{kWh}$. The difference between $\mathrm{CO}_{2}$ per $\mathrm{kWh}$ found from HOMER and the average value is called as error. As the average $\mathrm{CO}_{2}$ emission per $\mathrm{kWh}$ energy generation is $640 \mathrm{~g}$, the relative error in the case of different fuels can be easily deduced. In Bangladesh, natural gas, coal and diesel are the main fuel and their contributions in power generation are not equal. Thus, the resultant relative error from different fuels is unequal.

\section{Discussion}

\subsection{Strategies for GHG emission mitigation}

The GHG emission from the fossil fuel power stations influences significantly global warming level. Therefore the mitigation of such emission from conventional fossil fuel power station is very essential now-a-days. Several factors are identified in this paper which are directly involved in GHG emission from fossil fuel power station in Bangladesh, i.e., carbon $\&$ sulfur content of the fuel, amount of energy generation, technology used, energy efficiency and improper waste disposal techniques and so on. The low carbon development programs cover low GHG emission, reduce vulnerabilities of climate change, use of renewable energy and less effect on socio-economic aspects and make the energy sector sustainable [Lee et. al. 2018]. With the increasing electricity demand, GHG emission rate is increasing with the same proportion of rising electricity demand in Bangladesh. As it is obvious, government of Bangladesh has taken a large number of initiatives for establishing fossil fuel based power station to meet the huge demand of electricity. Thus, it is crucial to find out the best system for reducing GHG emission. The study suggested several mitigating procedure in this section corresponding to fossil fuel power stations in Bangladesh.

\subsubsection{Integration of renewable energy sources}

Renewable energy resources give the reasonable amount of GHG emission reduction than fossil-based power station. By integrating renewable energy resources, it would be a meaningful option for reducing GHG emission. Huge potentiality of renewable resources like solar, biogas/biomass can be employed to generate power in Bangladesh. Studies show that renewable resources used in electricity generation help to curtail the GHG emission [Amponsah et. al. 2014; Rahman et. al. 2018]. Another comparative analysis performed claims that renewable resources like nuclear, wind and hydro-electric power have less environmental pollution than coal fired power plant [Siddiqui et. al. 2017]. Fig. 6 illustrates renewable resources, such as solar, wind, nuclear, hydro, geo-thermal and biomass, have the least amount 
of $\mathrm{CO}_{2}$ emission than other non-renewable sources. Biogas/biomass has the highest amount of $\mathrm{CO}_{2}$ emission than other renewable resources. Although utilization of biogas resources makes the environment clean, fresh and free from bad smell. It also gives fertilizer which is beneficial for the agriculture and fish feed.

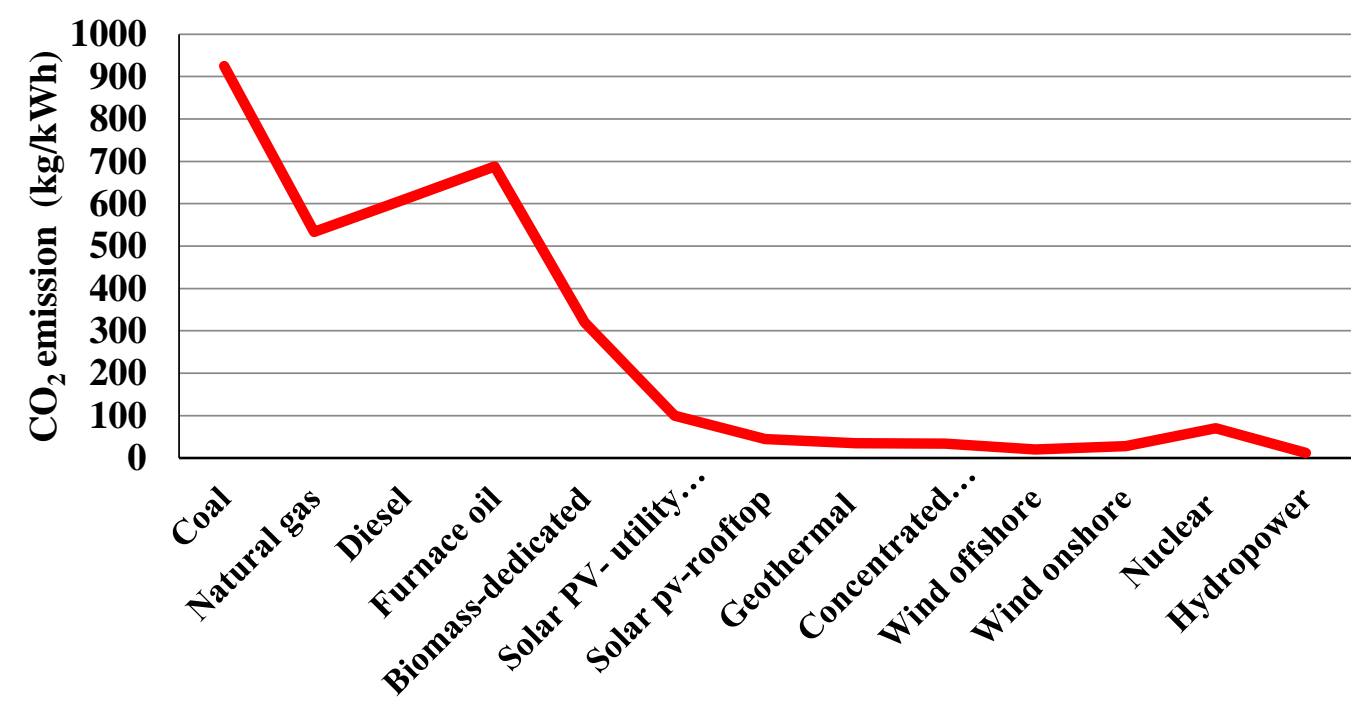

Fig. 6: $\mathrm{CO}_{2}$ emission from various resources [IPCC 2014]

Fig. 7 exhibits technological advancement that may reduce GHG emission remarkably [Ravindra et. al. 2019]. However, the incorporation of renewable resources for electricity generation becomes the most affordable and reliable process for sustainable development.

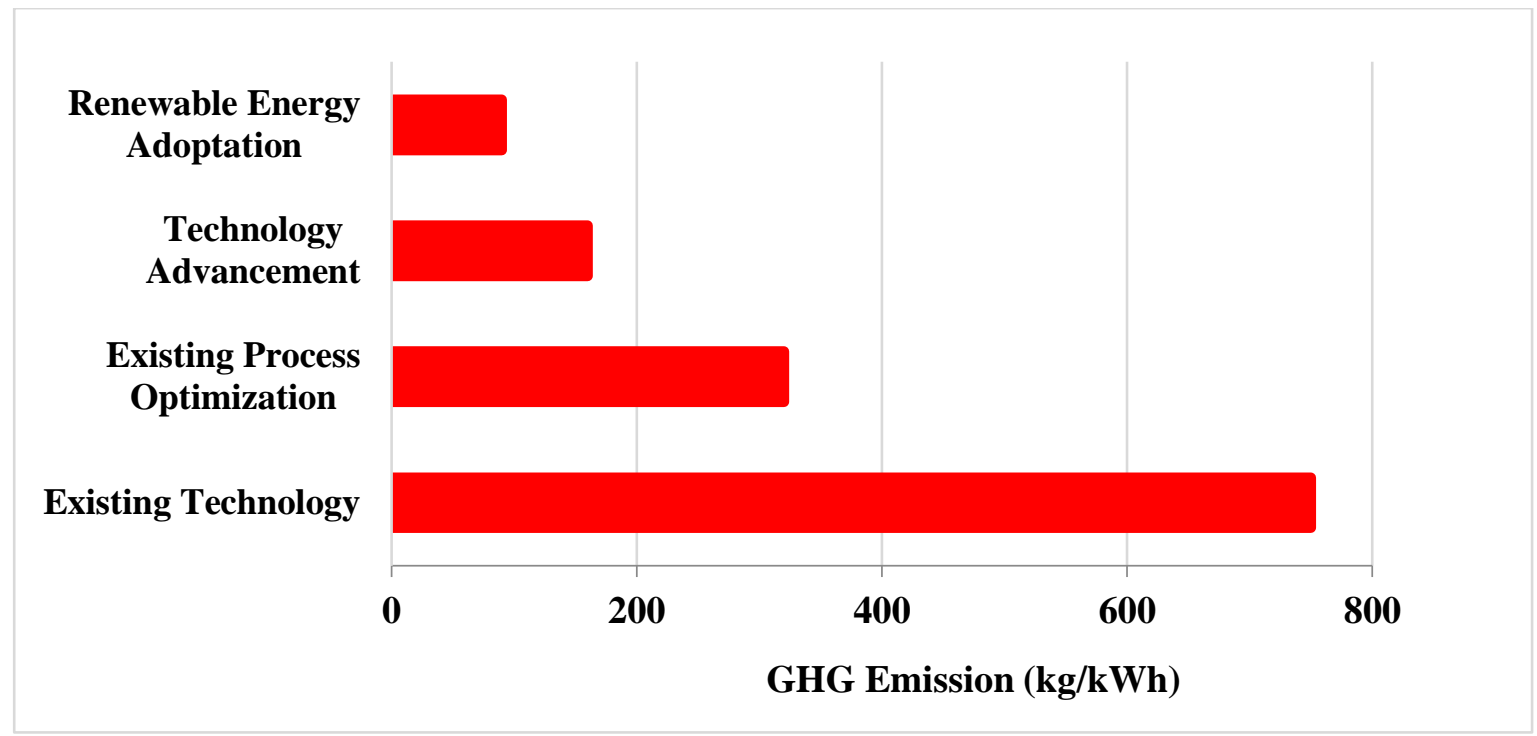

Fig. 7: GHG Emission reduction for different cases

\subsubsection{Tree plantation around the power plant}


Trees capture carbon particulates and release oxygen $\left(\mathrm{O}_{2}\right)$ to the atmosphere by means of photosynthesis. The captured carbon is then converted into branches, roots and leaves using solar energy. Thus tree plantation is imperative option around the power plants where $\mathrm{CO}_{2}$ produces for every $\mathrm{kWh}$ generation. There are many trees in Bangladesh, which absorb $\mathrm{CO}_{2}$ appreciably. It is also shown in a research that pollutants like $\mathrm{CO}_{2}$ exhausted by a plant are useful and beneficial for the trees to grow up faster [Aba et. al. 2017]. Planting trees would be a cost-effective and eco-friendly way to bring down the pollutions due to GHG emission from the power generating station. The value of $\mathrm{CO}_{2}$ captured by a tree in pounds can be represented by the equation (8), (9) given below [Amin et. al. 2019]. Therefore, tree plantation would be a constructive way to resolve particulates from coal burning process in power plant.

$$
\begin{aligned}
& W=\frac{0.25 * D^{2} * H * 120 \% * 72.5 \% * 50 \% * 3.6663}{\text { Tree_Age }(\text { year })} ;(\text { when } D<11 \text { inches })(8) \\
& W=\frac{0.15 * D^{2} * H * 120 \% * 72.5 \% * 50 \% * 3.6663}{\text { Tree_Age }(\text { year })} ;(\text { when } D>=11 \text { inches })(9)
\end{aligned}
$$

where $W=$ Weight of the $\mathrm{CO}_{2}$ captured by a tree per year in pounds, $D=$ Diameter in inches and $H=$ Tree height in feet.

\subsubsection{Use of modern technologies}

As a large number of power stations are operated since long term in Bangladesh, the technologies need to be changed to increase energy efficiency and to decrease GHG emission. Aged equipment causes more emission than the new one. Improper combustion of fuel is the leading factor for producing GHG emission. Air-fuel ratio must be maintained to obtain extensive combustion of fuel which increases the energy efficiency. When burning a fuel in a combustion chamber, there some heat energy out as exhaust and if the burning are not properly happened then the particulate becomes pollutant. In the case of coal based power plant, monitoring performance of optimized pulverize coal can be a fruitful strategy for augmenting energy efficiency. Additionally, lower rank coals (Brown coal) is dewatered to recover the calorific value and then pulverized for proper combustion. Thus, the energy conversion efficiency of coal will be enhanced [Huisingh et. al. 2015]. Using modern technology, the proper combustion of the fuel can be ensured and resulting energy recovering efficiency will be improved.

Another point is that open cycle power plant should be converted into combined cycle power plant to utilize the exhaust heat which may affect the environmental sustainability. A study interconnected to the diminution of GHG emission from power plants indicates that using modern technologies to control the $\mathrm{CO}_{2}$ emission plays a prominent role [Petrescu et. al. 2017; Bui, Mai, et. al. 2018]. Table [4] validates the efficiency data for coal, diesel and natural gas with various technologies. 
Table [4]: Efficiency for fossil fuel power plant [Li, Aijun, et. al. 2018]

\begin{tabular}{|c|c|c|}
\hline Fuel type & Generation Technologies & Efficiency \\
\hline \multirow{3}{*}{ Coal } & Subcritical & $37 \%-39 \%$ \\
\cline { 2 - 3 } & Supercritical & $45 \%$ \\
\cline { 2 - 3 } & Ultra-supercritical & $50 \%$ \\
\cline { 2 - 3 } & IGCC (Integrated gasification Combined Cycle) & $50 \%$ \\
\hline \multirow{3}{*}{ Oil } & Steam turbine & $37.5 \%-39 \%$ \\
\cline { 2 - 3 } & Open cycle & $30 \%-39.5 \%$ \\
\cline { 2 - 3 } & Combined cycle & $46 \%$ \\
\hline \multirow{3}{*}{ Natural gas } & Steam turbine & $37.5 \%$ \\
\cline { 2 - 3 } & Open cycle & $46 \%-39.5 \%$ \\
\cline { 2 - 3 } & Combined cycle & $46 \%$ \\
\hline
\end{tabular}

Fig. 9 shows that ultra-supercritical and IGCC technology give the higher efficiency in case of coal based power plant. In the case of combined cycle power plant, the efficiency increased up to $60 \%$ with the use of natural gas. Energy efficiency improvement plan comprises the following tools and techniques- such as, plant assessment, master plan and implementation of each phase properly. The lack of technical skill, initiatives for improving energy efficiency and ignorance of the legal policy can be major barrier for a power plant analyzed in a study[Kangas et. al. 2018].

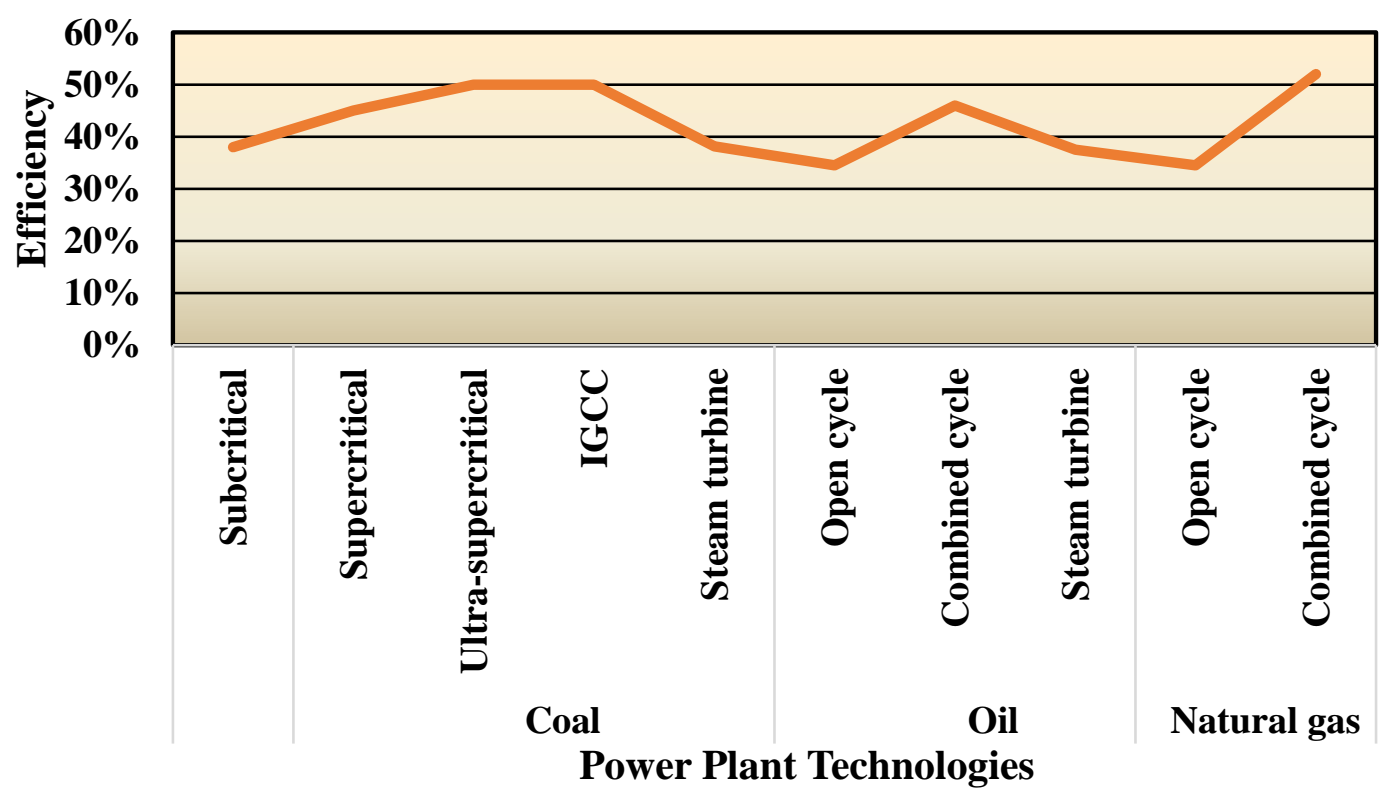

Fig. 9: Efficiency variation for different technologies [Li, Aijun, et al]

Zhang et. al. described several methods to improve the energy efficiency of fossil fuel power plants which will be cost-effective and eco-friendly [Zhang et. al. 2015]. Recent progression of technologies (i.e. high efficiency generators \& transformers, variable frequency drives, power quality checking instrumentation and switchgear equipment etc.) for monitoring, controlling 
and optimizing the whole process can be an effective way to ameliorate the energy efficiency of the power plants.

\subsubsection{Use of carbon capture \& storage (CCS) technology}

Fossil fuel power plants originate substantial amount of $\mathrm{CO}_{2}$ emissions throughout the atmosphere which is demonstrating as the ruling cause of climate change. Among other $\mathrm{CO}_{2}$ mitigation techniques, $\mathrm{CCS}$ is supposed to be a potent technology to curtail the $\mathrm{CO}_{2}$ emissions from fuel combustion. CCS technology is used for capturing and storing carbon where exists three technological ways for capturing $\mathrm{CO}_{2}$ from power plants: post-combustion, precombustion and oxy-fuel combustion [Petrescu et. al. 2019]. In this process, the coal is chemically washed, gasified and finally burned to produce steam. To remove the $\mathrm{SO}_{2}$, the subsequent flue gas treats the steam and re-burned to make $\mathrm{CO}_{2}$ in the flue gas parsimoniously recoverable \& storable. Although CCS technology absorbs carbon contamination from the fossil fuel power plant but it reduces the overall plant efficiency. On the other hand, recent research demonstrates that, approximately $60 \%$ of the energy penalty comes from the carbon capture process itself, $30 \%$ originates from carbon compression and remaining $10 \%$ comes from electricity requirement for necessary pumps and fans [Bui, Mai, et al. 2018]. In addition, CCS technology utilizes $10 \%$ - 40\% of the energy produced by a power plant [Groesbeck et. al. 2018]. To cut down the cost of carbon capturing process, different research explained the utilization of biomass or waste derived bio char for carbon capturing technology [Kolster, Clea et. al. 2017].

Bio char is produced by pyrolysis of organic wastes in the absence of oxygen. This is a cheapest mode of carbon capturing process along with proper waste management which resolves the issue of landfill burden and $\mathrm{CO}_{2}$ emissions. In a research, it is found that bio char made of waste wood saw dust improves the air quality and increases the carbon capture and sequestration capability by reducing 8.33 times [Liu et. al. 2019]. These researches reveal that, solid biofuel reduces the cost of carbon capturing with technical, financial and environmental benefits. In addition, bio char reduces nitrate level by increasing doses made from solid bio fuels [Kua HW et. al. 2019; Maroušek J et. al. 2017]. Fig. 8 shows that the use of CCS technology spread out clean gas with reduced amount of $\mathrm{CO}_{2}$ and other pollutants.

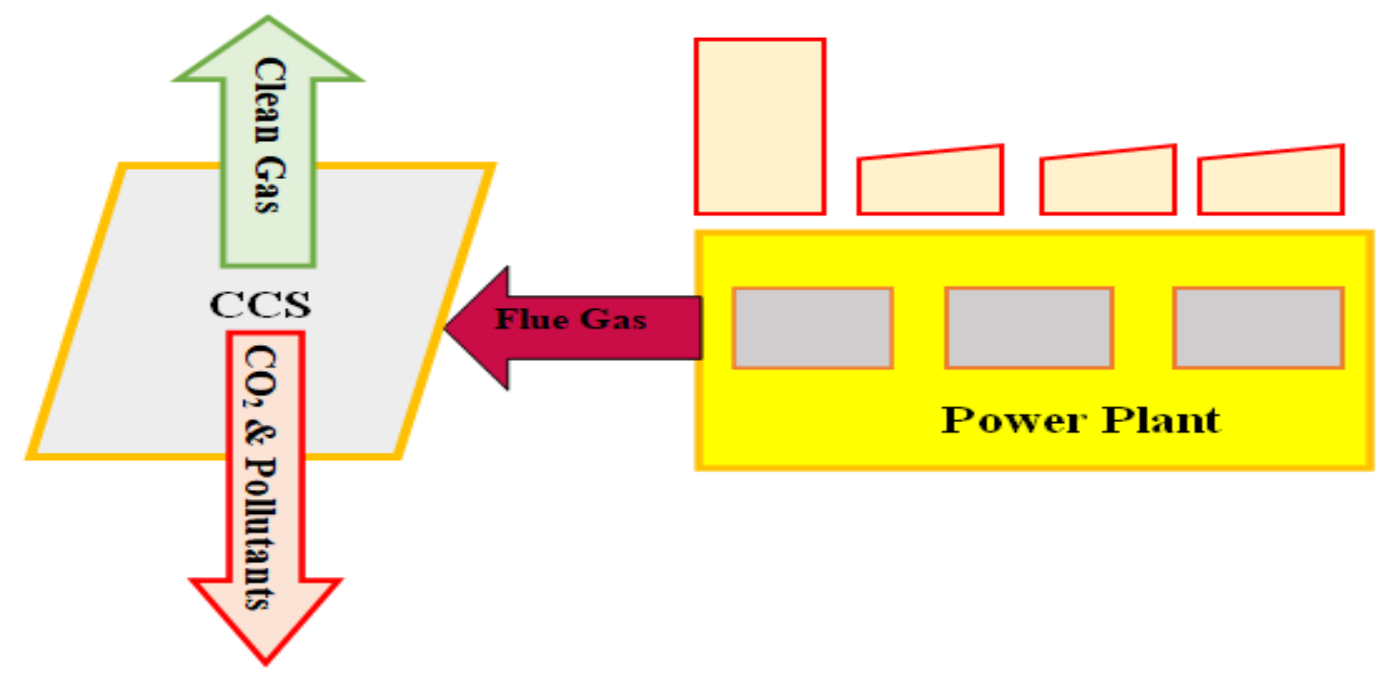

Fig. 8: CCS technology used in power plant 
Table [3]: Emissions to atmosphere with CCS in kg/MWh [Booras et. al. 2013]

\begin{tabular}{|c|c|c|c|}
\hline $\begin{array}{c}\text { GHG } \\
\text { Parameters }\end{array}$ & $\begin{array}{c}\text { Natural gas } \\
\text { Combined Cycle }\end{array}$ & Pulverized coal & $\begin{array}{c}\text { Integrated gasification } \\
\text { combined cycle (IGCC) }\end{array}$ \\
\hline $\mathrm{CO}_{2}$ & $0.43(-89 \%)$ & $1.07(-87 \%)$ & $0.97(-88 \%)$ \\
\hline $\mathrm{NO}_{\mathrm{x}}$ & $0.11(+22 \%)$ & $0.77(+31 \%)$ & $0.1(+11 \%)$ \\
\hline $\mathrm{SO}_{\mathrm{x}}$ & - & $0.001(-99.7 \%)$ & $0.33(+17.9 \%)$ \\
\hline
\end{tabular}

Table [3] shows the GHG emission to atmosphere with CCS and percentage shown in brackets indicates increased or decreased amount GHG parameters with the plant without CCS. Levelized cost of $\mathrm{CO}_{2}$ avoided represents overall cost of using CCS among the plants with and without CCS. Mathematically it can be said as-

$$
\text { Cost_of_CO } \mathrm{O}_{2} \text { avoided }=\frac{L C O E_{C C S}-L C O E_{R E F}}{\left.\left(t C O_{2} / M W h\right)_{R E F}-t C O_{2} / M W h\right)_{C C S}}
$$

where $L C O E_{C C S}, L C O E_{R E F}$ represents levelized cost of energy with CCS and without CCS respectively [Cebrucean et. al. 2014].

\subsubsection{Selection of fuels}

Fuel selection is important for reducing GHG emission from the fossil fuel power plants. There is a wide variation in $\mathrm{CO}_{2}$ emission per $\mathrm{kWh}$ of electricity generation observed due to energy conversion efficiency, fuel selection, and plant age. However, a steady decaying in average GHG emission per MWh is perceived with the changes to low carbon fuels (i.e. natural gas) to carbon-intensive fuel (i.e. coal) [Gingerich et. al. 2018]. The difference of GHG emission from different coal can also be seen in table [5] given by European Environment Agency (EEA) in 2008 [Volker quaschning 2015].

Table [5]: Different fuels with GHG emission parameter

\begin{tabular}{|c|c|c|c|c|c|}
\hline Pollutant & Hard coal & Brown coal & Fuel oil & Other oil & Gas \\
\hline $\mathbf{C O}_{\mathbf{2}}(\mathbf{k g} / \mathbf{k J})$ & 94,600 & 101,000 & 77,400 & 74,100 & 56,100 \\
\hline $\mathbf{S O}_{\mathbf{2}}(\mathbf{k g} / \mathbf{k J})$ & 765 & 1,361 & 1,350 & 228 & 0.68 \\
\hline $\mathbf{N O}_{\mathbf{x}}(\mathbf{k g} / \mathbf{k J})$ & 292 & 183 & 195 & 129 & 93.3 \\
\hline $\mathbf{C O}(\mathbf{k g} / \mathbf{k J})$ & 89.1 & 89.1 & 15.7 & 15.7 & 14.5 \\
\hline $\begin{array}{c}\text { Non methane organic compounds } \\
(\mathbf{k g} / \mathbf{k J})\end{array}$ & 4.92 & 7.78 & 3.70 & 3.24 & 1.58 \\
\hline Particulate matter $(\mathbf{k g} / \mathbf{k J})$ & 1,203 & 3,254 & 16 & 1.91 & 0.1 \\
\hline Flue gas volume total $\left(\mathbf{m}^{\mathbf{3} / G J)}\right.$ & 360 & 444 & 279 & 276 & 272 \\
\hline
\end{tabular}

Almost all the power plants in Bangladesh are based on coal. Therefore, selection of fuel like clean coal would be a new concept for reducing environmental pollution and mitigating the climate change. It provides a way to enhance both efficiency \& environmental acceptance in coal based power plant. Usually, clean coal technology deals with the atmospheric problems 
forming from burning coal. The gaseous emission is initiated by the thermal disintegration of the coal which has adverse effect on the environment $\&$ human health. To overcome these negative impacts from coal based power generation, clean coal technologies are discovering its popularity to diminution GHG emissions to the atmosphere [C2ES 2018]. Techniques that are involved with the decline of GHG emission from coal power plants include chemically washing minerals and impurities from the coal, integrated gasification combined cycle (IGCC), use of advance technology for treating flue gases. These techniques help to eliminate pollutants to a standard level and at higher efficiency.

\subsubsection{Optimization process}

Conventional power plant uses up to $7 \%$ to $15 \%$ of its own electrical power to operate its electrical systems [EPRI 2011]. This power is generated by the plant, although it is not reaching the grid. Optimization process usually deals with the performance of combustion and steam processes. EBOP (Electrical Balance of Plant) is an important terms that describes how the all electrical loads are getting power. By making electrical components more efficient, the losses can be minimized for increasing efficiency [Ashiquzzaman et. al. 2019]. Mainly, different motors that drive pumps, fans, light and auxiliary systems are in a power plant. Older motors are less efficient than today's standard. The pump or fan runs at constant power despite of load requirements. The air flow or water flow is controlled with bypasses that results insignificant energy waste. It can be solved by using variable speed drives with high efficiency.

\subsubsection{Waste disposal techniques}

Waste (i.e. solid particles, exhaust heat) releases from the power plant affects the environment seriously. These wastes are generally mixed with the water, land or atmosphere. Wastes can be recycled or disposed properly using appropriate technologies. In Bangladesh, older power plant operates at open cycle form and produces more wastes or pollutants. Proper management of the wastes plays a noteworthy role for reducing GHG emission. Waste to energy (WTE) projects can improve the environmental health by less land filling the wastes generated from power plants [NETL 2018; Cucchiella et. al. 2017].

\subsubsection{Ageing effects}

Electrical asset (i.e. generators, transformers, cables, switchgear, accessories and so on ) influences greatly to different environmental and operational stress factors throughout their entire service life. Thus ageing and degradation in electrical insulating materials leads to the early and unexpected failure of the assets. A research performed in a thermal power plant demonstrates that, the root cause analysis and predictive maintenance by smart monitoring techniques can help to solve the ageing problem of a power plant equipment [Nagarjun, Y., et. al. 2015]. Efficiency of the equipment (i. e Boiler, generator etc.) used in power plant can be decreased due to ageing effect. Another point is that, power plant of Bangladesh always runs on peak demand. So, maintenance of the equipment does not happen periodically. Only maintenance is done whenever equipment shuts down unexpectedly. Thus the equipment efficiency decreases. This can be minimized by regular maintenance of the equipment used in power station. 


\subsection{Implications of findings}

Rising of GHG emission from fossil fuel power plants around the world becomes a burning issue now-a-days. This paper firstly determines the GHG emission from the fossil fuel power plants in Bangladesh and thereafter a comparative analysis is presented among various fossil fuel based power generating stations. Therefore this study offers huge implications for analysis of the GHG emission. The GHG emission corresponding to conventional power plants can be reduced remarkably by using the proposed mitigation strategies which is discussed in this work.

It is predicted by using extrapolation techniques that Bangladesh will be the prominent $\mathrm{CO}_{2}$ emitter from fossil fuel power stations in the financial year 2024-2025. The amount of $\mathrm{CO}_{2}$ for 1,32,520 GWh electricity generation is found 83,000 Metric ton which will be dangerous for such densely populated country. While developed countries are trying to limits fossil fuel consumption with increasing renewable energy generation, the power sector of Bangladesh is expanding the generation capacity by coal based power plant [Ashiquzzaman et. al. 2019; Zaman et. al. 2018]. Therefore, the industry professionals and environmentalists are looking towards the amount of GHG emission from the power sector.

The average $\mathrm{CO}_{2}$ emission per $\mathrm{kWh}$ is assumed as $640 \mathrm{~g}$ [Das et. al. 2017]. However, the present work demonstrates it varies with type of fuels, the technology used and also on the ageing effects. Although, $\mathrm{CO}_{2}$ covers the major portion of $\mathrm{GHG}$ emission, there are also other gases affecting environmental pollution significantly. Hence, this work identifies the amount of $\mathrm{CO}, \mathrm{SO}_{2}, \mathrm{NO}_{\mathrm{x}}$, unburned hydrocarbon and other particulate matters produced from fossil fuel power plants as shown in Table [1]. Addition to this, the relative error for different fossil fuel based GHG emission is explained in Table [2]. This error rate indicates that the real value differs from theoretical value due to having its chemical composition and technology used by the power plants.

Existing coal based power plants in Bangladesh are operating on the oldest technology which is also a reason for increasing GHG emission. Different technological approaches are discussed in this paper to highlight the issues of energy efficiency with lowering GHG emission. Renewable resources showed better performance regarding GHG emission downing capacity [Rahman et. al. 2018; Ravindra et. al. 2019]. Thus, the authors encourage to promote renewable based power generation which notably reduces GHG emission and energy cost. Addition to these, proper waste management can be performed using biomass based power \& heat generation by keeping environment neat and clean [Song et. al. 2018].

Tree plantation around the power plants could be an imperative way to cut the GHG emission as it absorbs $\mathrm{CO}_{2}$ considerably. However, the absorption rate depends on the size and height of the trees. Therefore, it is suggested to planting trees around the plants which are growing faster. Another important techniques discussed in this paper is CCS technology which is very much expensive and consumes energy from the power station itself. Consequently, authors' of this paper recommend for using bio char instead of CCS technology. Bio char is made of waste wood which improves the air quality and reduces environmental pollution by capturing carbon [Liu et. al. 2019]. 
Besides these, older power plants having apparatus with ageing effect leads to GHG emission. It is also encouraged by the authors to take steps regarding periodic and regular maintenance of the power plants apparatus.

As the study suggested several GHG mitigating procedures to overcome the environmental pollution during electricity generation by burning fossil fuels, it will surely help to build sustainable infrastructure in Bangladesh as well as in the world.

\section{Conclusions}

Higher GHG emission caused by conventional power station has a detrimental impact on the environment and human health leading to hinder in sustainable development. This research forecasts that Bangladesh will be placed one of the most $\mathrm{CO}_{2}$ emitting countries in the financial year of 2024-25 with 83,000 Metric tons of $\mathrm{CO}_{2}$ for $1,32,520 \mathrm{GWh}$ electricity generation. Increasing electricity demand in Bangladesh leads to establish more conventional fossil fuel power stations which is a key reason for proliferating GHG emission. This work demonstrates that coal, diesel, and natural gas-based power station emits $0.90 \mathrm{~kg}, 0.76 \mathrm{~kg}$, and $0.566 \mathrm{~kg}$ of $\mathrm{CO}_{2}$ per $\mathrm{kWh}$, respectively. Besides, other GHG gases such as $\mathrm{CO}, \mathrm{SO}_{2}, \mathrm{NO}_{\mathrm{x}}$, unburned hydrocarbons, and other particulate matters are determined for per kWh electricity generation in Bangladesh. This measurement will give a clear understanding of the $\mathrm{CO}_{2}$ emission rate from three major fossil fuels used in Bangladesh for power generation. It is observed that the amount of GHG emission varies according to fuel composition, combustion techniques and the technology used in power generation.

Several mitigation procedures are presented to conclude that GHG emission can be significantly reduced by considering renewable resources, tree plantation, increasing energy efficiency, carbon capture \& storage technology, use of clean coal, use of bio char made of solid waste, optimization process and consideration of aging effect. Although CCS technology is very effective for carbon capture, the technology consumes energy and increases cost that provokes to choose an alternative way of $\mathrm{CO}_{2}$ emission reduction. Moreover, the authors suggest available renewable resources would be a potential solution that offers a significant reduction of GHG emissions effectively.

Although this research represents the case of Bangladesh, analysis for fossil fuel power stations and corresponding GHG emissions around the world can be a reliable option for future research directions. It is also recommended that the technological advancement in renewable energy integration into the grid and optimization process lead to low GHG emission rate during electricity generation. Mitigation strategies presented in the paper can be easily executed by the power sector with the financial \& technological support from the Government of Bangladesh, global partners, and developed countries.

\section{Conflict of Interest}

Author declares there is no conflict of interest regarding publication of the paper. 


\section{References}

Amin, S.B. and Rahman, S., 2019. Renewable Energy Practices in Bangladesh. In Energy Resources in Bangladesh(pp. 93-96). Springer, Cham. https://doi.org/10.1007/978-3-03002919-7_19

Smith, C.J., Forster, P.M., Allen, M., Fuglestvedt, J., Millar, R.J., Rogelj, J. and Zickfeld, K., 2019. Current fossil fuel infrastructure does not yet commit us to $1.5 \mathrm{C}$ warming. Nature communications, 10(1), p.101. https://www.nature.com/articles/s41467-018-07999-w

Eyre, N., Darby, S.J., Grünewald, P., McKenna, E. and Ford, R., 2018. Reaching a 1.5 C target: socio-technical challenges for a rapid transition to low-carbon electricity systems. Philosophical Transactions of the Royal Society A: Mathematical, Physical and Engineering Sciences, 376(2119), p.20160462. https://doi.org/10.1098/rsta.2016.0462.

Baky, M.A.H., Rahman, M.M. and Islam, A.S., 2017. Development of renewable energy sector in Bangladesh: Current status and future potentials. Renewable and Sustainable Energy Reviews, 73, pp.1184-1197. https://doi.org/10.1016/j.rser.2017.02.047

Zaman, R., Brudermann, T., Kumar, S. and Islam, N., 2018. A multi-criteria analysis of coalbased power generation in Bangladesh. Energy policy, 116, pp.182-192. https://doi.org/10.1016/j.enpol.2018.01.053

Wilson, I.G. and Staffell, I., 2018. Rapid fuel switching from coal to natural gas through effective carbon pricing. Nature Energy, 3(5), p.365. https://www.nature.com/articles/s41560018-0109-0

Weldu, Y.W., Assefa, G. and Jolliet, O., 2017. Life cycle human health and ecotoxicological impacts assessment of electricity production from wood biomass compared to coal fuel. Applied energy, 187, pp.564-574. https://doi.org/10.1016/j.apenergy.2016.11.101

Dinca, C., Marculescu, C., Badea, A. and Gheorghe, C., 2008, October. Critical analysis of GHG emissions generate by the fossil fuel power plant. In WSEAS International Conference. Proceedings. Mathematics and Computers in Science and Engineering (No. 10). WSEAS. https://www.researchgate.net/profile/Adrian_Badea/publication/262399109_Critical_analysis _of_GHG_emissions_generate_by_the_fossil_fuel_power_plant/links/56b09a5a08ae8e37215 059

Gilbert, A.Q. and Sovacool, B.K., 2018. Carbon pathways in the global gas market: An attributional lifecycle assessment of the climate impacts of liquefied natural gas exports from the United States to Asia. Energy policy, 120, pp.635-643. https://doi.org/10.1016/j.enpol.2018.05.063 
Khan, I., Jack, M.W. and Stephenson, J., 2018. Analysis of greenhouse gas emissions in electricity systems using time-varying carbon intensity. Journal of cleaner production, 184, pp.1091-1101. https://doi.org/10.1016/j.jclepro.2018.02.309

Song, Q., Wang, Z., Li, J., Duan, H., Yu, D. and Liu, G., 2018. Comparative life cycle GHG emissions from local electricity generation using heavy oil, natural gas, and MSW incineration in Macau. Renewable and Sustainable Energy Reviews, 81, pp.2450-2459. https://doi.org/10.1016/j.rser.2017.06.051

Kamyab, H., Lim, J.S., T Khademi, H.W., Ahmad, R. and Hashim, H., 2015. Greenhouse gas emission of organic waste composting: A case study of universiti teknologi malaysia green campus flagship project. Jurnal Teknologi, 74(4), pp.113-117. https://jurnalteknologi.utm.my/index.php/jurnalteknologi/article/view/4618

Yu, X., Chen, H., Wang, B., Wang, R. and Shan, Y., 2018. Driving forces of CO2 emissions and mitigation strategies of China's National low carbon pilot industrial parks. Applied energy, 212, pp.1553-1562. https://doi.org/10.1016/j.apenergy.2017.12.114

Hoque, M.R., Hasan, S., Banik, N.L., Ahmed, N. and Chowdhury, S.R., 2019. Low-Carbon Energy Technologies: Potentials of Solar and Nuclear Energy Sources for Sustainable Economic Development in Bangladesh. International Journal of Technology for Business (IJTB), 1(1), pp.24-32. http://hdl.handle.net/10419/194868

Kåberger, T., 2018. Progress of renewable electricity replacing fossil fuels. Global Energy Interconnection, 1(1), pp.48-52. https://doi.org/10.14171/j.2096-5117.gei.2018.01.006

Zhou, N., Price, L., Yande, D., Creyts, J., Khanna, N., Fridley, D., Lu, H., Feng, W., Liu, X., Hasanbeigi, A. and Tian, Z., 2019. A roadmap for China to peak carbon dioxide emissions and achieve a $20 \%$ share of non-fossil fuels in primary energy by 2030. Applied energy, 239, pp.793-819. https://doi.org/10.1016/j.apenergy.2019.01.154

Karmaker, A.K., Ahmed, M.R., Hossain, M.A. and Sikder, M.M., 2018. Feasibility assessment \& design of hybrid renewable energy based electric vehicle charging station in Bangladesh. Sustainable cities and society, 39, pp.189-202. https://doi.org/10.1016/j.scs.2018.02.035

Rahman, K.M., Edwards, D.J., Melville, L. and El-Gohary, H., 2019. Implementation of Bioenergy Systems towards Achieving United Nations' Sustainable Development Goals in Rural Bangladesh. Sustainability, 11(14), p.3814. https://doi.org/10.3390/su11143814

Amin, S.B. and Rahman, S., 2019. The Role of ICT in Energy Sector: Towards a Digital Bangladesh by 2021. In Energy Resources in Bangladesh (pp. 31-35). Springer, Cham. https://link.springer.com/chapter/10.1007/978-3-030-02919-7_6 
Sharif, S.I., Anik, M.A.R., Al-Amin, M. and Siddique, M.A.B., 2018. The Prospect of renewable energy resources in Bangladesh: A study to achieve the national power demand. Energy and Power, 8(1), pp.1-6. DOI: 10.5923/j.ep.20180801.01

Das, A., Halder, A., Mazumder, R., Saini, V.K., Parikh, J. and Parikh, K.S., 2018. Bangladesh power supply scenarios on renewables and electricity import. Energy, 155, pp.651-667. https://doi.org/10.1016/j.energy.2018.04.169

Rashid, S., Rana, S., Shezan, S.K.A., Karim, S.A. and Anower, S., 2017. Optimized design of a hybrid PV-wind-diesel energy system for sustainable development at coastal areas in Bangladesh. Environmental progress \& sustainable energy, 36(1), pp.297-304. https://doi.org/10.1002/ep.12496

Islam, K.N. and Jashimuddin, M., 2017. Reliability and economic analysis of moving towards wastes to energy recovery based waste less sustainable society in Bangladesh: The case of commercial capital city Chittagong. Sustainable Cities and Society, 29, pp.118-129. https://doi.org/10.1016/j.scs.2016.11.011

Nassar, I.A. and Abdella, M.M., 2018. Impact of replacing thermal power plants by renewable energy on the power system. Thermal Science and Engineering Progress, 5, pp.506-515. https://doi.org/10.1016/j.tsep.2018.02.002

Owusu, P.A. and Asumadu-Sarkodie, S., 2016. A review of renewable energy sources, sustainability issues and climate change mitigation. Cogent Engineering, 3(1), p.1167990. https://doi.org/10.1080/23311916.2016.1167990

Chapman, A.J., McLellan, B.C. and Tezuka, T., 2018. Prioritizing mitigation efforts considering co-benefits, equity and energy justice: Fossil fuel to renewable energy transition pathways. Applied energy, 219, pp.187-198. https://doi.org/10.1016/j.apenergy.2018.03.054

Walmsley, M.R., Walmsley, T.G. and Atkins, M.J., 2018. Linking greenhouse gas emissions footprint and energy return on investment in electricity generation planning. Journal of cleaner production, 200, pp.911-921. https://doi.org/10.1016/j.jclepro.2018.07.268

Dalir, F., Motlagh, M.S. and Ashrafi, K., 2018. A dynamic quasi comprehensive model for determining the carbon footprint of fossil fuel electricity: A case study of Iran. Journal of Cleaner Production, 188, pp.362-370. https://doi.org/10.1016/j.jclepro.2018.03.274

Audoly, R., Vogt-Schilb, A., Guivarch, C. and Pfeiffer, A., 2018. Pathways toward zerocarbon electricity required for climate stabilization. Applied energy, 225, pp.884-901. https://doi.org/10.1016/j.apenergy.2018.05.026

Hondo, H., 2005. Life cycle GHG emission analysis of power generation systems: Japanese case. Energy, 30(11-12), pp.2042-2056. https://doi.org/10.1016/j.energy.2004.07.020 
Cheng, C.T., Miao, S.M., Luo, B. and Sun, Y.J., 2017. Forecasting monthly energy production of small hydropower plants in ungauged basins using grey model and improved seasonal index. Journal of Hydroinformatics, 19(6), pp.993-1008. https://doi.org/10.2166/hydro.2017.062

Tan, S.T., Hashim, H., Hoo, P.Y., Rashid, A.H.A., Lim, J.S. and Ho, W.S., 2017. Mitigation the transboundary haze in ASEAN country: biomass to energy GHG emission assessment. Energy Procedia, 105,

pp.1178-1183. https://doi.org/10.1016/j.egypro.2017.03.406

Saikawa, E., Trail, M., Zhong, M., Wu, Q., Young, C.L., Janssens-Maenhout, G., Klimont, Z., Wagner, F., Kurokawa, J.I., Nagpure, A.S. and Gurjar, B.R., 2017. Uncertainties in emissions estimates of greenhouse gases and air pollutants in India and their impacts on regional air quality. Environmental Research Letters, 12(6), p.065002. https://iopscience.iop.org/article/10.1088/1748-9326/aa6cb4/meta

SREDA 2019, Sustainable and Renewable Energy Development Authority (SREDA), www. sreda.gov.bd. (accessed on 01 August 2019).

Das, B.K., Hoque, N., Mandal, S., Pal, T.K. and Raihan, M.A., 2017. A techno-economic feasibility of a stand-alone hybrid power generation for remote area application in Bangladesh. Energy, 134, pp.775-788. https://doi.org/10.1016/j.energy.2017.06.024

Kibria, G., Haroon, A.K. and Nugegoda, D., 2018. Low-Carbon Development (LCD) Pathways in Australia, Bangladesh, China and India-A Review. Journal of Climate Change, 4(1), pp.49-61. https://content.iospress.com/articles/journal-of-climatechange/jcc180006

Bhuiyan, M.M.H., Islam, M.A., Hossain, M.I., Bagum, M.N., Akter, 2014 Y. and Chittagong, B., Analysis and comparison of different coal fields and imported coal in bangladesh. http://ijset.net/v3files/IJSET\%2014.pdf

Lee, C.T., Lim, J.S., Van Fan, Y., Liu, X., Fujiwara, T. and Klemeš, J.J., 2018. Enabling lowcarbon emissions for sustainable development in Asia and beyond. Journal of cleaner production, 176, pp.726-735. https://doi.org/10.1016/j.jclepro.2017.12.110

Amponsah, N.Y., Troldborg, M., Kington, B., Aalders, I. and Hough, R.L., 2014. Greenhouse gas emissions from renewable energy sources: A review of lifecycle considerations. Renewable and Sustainable Energy Reviews, 39, pp.461-475. https://doi.org/10.1016/j.rser.2014.07.087

Rahman, M.N., Sharif, M.R., Chowdhury, M.H.R., Ahamad, K.S. and Shoeb, M.A., 2018. Sustainability Analysis of Net Zero Emission Smart Renewable Hybrid System Solution in 
Bangladesh Rural Context. In Transition Towards 100\% Renewable Energy (pp. 365-378). Springer, Cham. https://link.springer.com/chapter/10.1007/978-3-319-69844-1_33

Siddiqui, O. and Dincer, I., 2017. Comparative assessment of the environmental impacts of nuclear, wind and hydro-electric power plants in Ontario: a life cycle assessment. Journal of Cleaner Production, 164, pp.848-860. https://doi.org/10.1016/j.jclepro.2017.06.237

IPCC 2014, Life-cycle greenhouse gas emissions of energy sources. Available online:https://en.wikipedia.org/wiki/Life-cycle_greenhousegas_emissions_of_energy_sources (accessed on 01 August 2019).

Ravindra, K., Singh, T. and Mor, S., 2019. Emissions of air pollutants from primary crop residue burning in India and their mitigation strategies for cleaner emissions. Journal of cleaner production, 208, pp.261-273. https://doi.org/10.1016/j.jclepro.2018.10.031

Aba, S.C., Ndukwe, O.O., Amu, C.J. and Baiyeri, K.P., 2017. The role of trees and plantation agriculture in mitigating global climate change. African Journal of Food, Agriculture, Nutrition and Development, 17(4), https://www.ajol.info/index.php/ajfand/article/view/163653

pp.12691-12707.

Amin, S.B. and Rahman, S., 2019. The Environment-Friendly Use of Coal in Bangladesh. In Energy Resources in Bangladesh (pp. 57-61). Springer, Cham. https://link.springer.com/chapter/10.1007/978-3-030-02919-7_11

Huisingh, D., Zhang, Z., Moore, J.C., Qiao, Q. and Li, Q., 2015. Recent advances in carbon emissions reduction: policies, technologies, monitoring, assessment and modeling. Journal of Cleaner Production, 103, pp.1-12. https://doi.org/10.1016/j.jclepro.2015.04.098

Petrescu, L., Bonalumi, D., Valenti, G., Cormos, A.M. and Cormos, C.C., 2017. Life Cycle Assessment for supercritical pulverized coal power plants with post-combustion carbon capture and storage. Journal of Cleaner Production, 157, pp.10-21. https://doi.org/10.1016/j.jclepro.2017.03.225

Bui, M., Adjiman, C.S., Bardow, A., Anthony, E.J., Boston, A., Brown, S., Fennell, P.S., Fuss, S., Galindo, A., Hackett, L.A. and Hallett, J.P., 2018. Carbon capture and storage (CCS): the way forward. Energy \& Environmental Science, 11(5), pp.1062-1176. DOI: $10.1039 / \mathrm{C} 7 \mathrm{EE} 02342 \mathrm{~A}$

Li, A., Zhang, A., Huang, H. and Yao, X., 2018. Measuring unified efficiency of fossil fuel power plants across provinces in China: An analysis based on non-radial directional distance functions. Energy, 152, pp.549-561. https://doi.org/10.1016/j.energy.2018.03.164

Kangas, H.L., Lazarevic, D. and Kivimaa, P., 2018. Technical skills, disinterest and nonfunctional regulation: Barriers to building energy efficiency in Finland viewed by energy 
service

Zhang, D., Liu, G., Chen, C., Zhang, Y., Hao, Y. and Casazza, M., 2019. Medium-to-longterm coupled strategies for energy efficiency and greenhouse gas emissions reduction in Beijing (China). Energy policy, 127, pp.350-360. https://doi.org/10.1016/j.enpol.2018.12.030

Bui, M., Adjiman, C.S., Bardow, A., Anthony, E.J., Boston, A., Brown, S., Fennell, P.S., Fuss, S., Galindo, A., Hackett, L.A. and Hallett, J.P., 2018. Carbon capture and storage (CCS): the way forward. Energy \& Environmental Science, 11(5), pp.1062-1176. DOI: 10.1039/C7EE02342A

Groesbeck, J.G. and Pearce, J.M., 2018. Coal with Carbon Capture and Sequestration is not as Land Use Efficient as Solar Photovoltaic Technology for Climate Neutral Electricity Production. Scientific reports, 8(1), p.13476. https://www.nature.com/articles/s41598-01831505-3

Kolster, C., Mechleri, E., Krevor, S. and Mac Dowell, N., 2017. The role of CO2 purification and transport networks in carbon capture and storage cost reduction. International Journal of Greenhouse Gas Control, 58, pp.127-141. https://doi.org/10.1016/j.ijggc.2017.01.014

Liu, S.H., 2019. Waste-Derived Biochar for CO2 Sequestration. In Biochar from Biomass and Waste (pp. 295-304). Elsevier. https://doi.org/10.1016/B978-0-12-811729-3.00016-9

Kua, H.W., Pedapati, C., Lee, R.V. and Kawi, S., 2019. Effect of indoor contamination on carbon dioxide adsorption of wood-based biochar-Lessons for direct air capture. Journal of cleaner production, 210, pp.860-871. https://doi.org/10.1016/j.jclepro.2018.10.206

Maroušek, J., Kolář, L., Vochozka, M., Stehel, V. and Maroušková, A., 2017. Novel method for cultivating beetroot reduces nitrate content. Journal of Cleaner Production, 168, pp.60-62. https://doi.org/10.1016/j.jclepro.2017.08.233

Booras, G., Davison, J., Ekstrom, C., Matuszewski, M. and Short, C., 2013. Toward a Common Method of Cost Estimation for CO2 Capture and Storage at Fossil Fuel Power Plants.

https://www.cmu.edu/epp/iecm/rubin/PDF\%20files/2012/CCS\%20Task\%20Force_White\%20 Paper_FINAL_Jan\%2015\%202013.pdf

Cebrucean, D., Cebrucean, V. and Ionel, I., 2014. CO2 capture and storage from fossil fuel power plants. Energy Procedia, 63, pp.18-26. https://doi.org/10.1016/j.egypro.2014.11.003

Gingerich, D.B. and Mauter, M.S., 2018. Retrofitting the regulated power plant: Optimizing energy allocation to electricity generation, water treatment, and carbon capture processes at 
coal-fired generating facilities. ACS Sustainable Chemistry \& Engineering, 6(2), pp.26942703. https://doi.org/10.1021/acssuschemeng.7b04316

Avagianos, I., Violidakis, I., Karampinis, E., Rakopoulos, D., Nanos, E., Polonidis, N., Papapavlou, C., Grammelis, P. and Kakaras, E., 2019. Thermal simulation and economic study of predried lignite production retrofit of a greek power plant for enhanced flexibility. Journal of Energy $\quad$ Engineering, 145(2), p.04019001. https://ascelibrary.org/doi/abs/10.1061/(ASCE)EY.1943-7897.0000591

C2ES 2018, Regulating power sector carbon emissions. Available online: https://www.c2es.org/content/regulating-power-sector-carbon-emissions/ (accessed on 06 August 2019).

EPRI 2011, Electricity use in power sector. Available online: https://pserc.wisc.edu/documents/publications/special_interest_publications/EPRI_Electricity _Use_Report_Final_1024651.pdf (accessed on 01 August 2019).

Ashiquzzaman, M., Hossain, M. and Nasrin, K.F., 2019. Study of Present Scenario of Power Sector in Bangladesh and Proposal to Minimize Losses for Increasing Efficiency. American Scientific Research Journal for Engineering, Technology, and Sciences (ASRJETS), 51(1), pp.136-155.

https://www.asrjetsjournal.org/index.php/American_Scientific_Journal/article/view/4610

NETL 2018, $\mathrm{CO}_{2}$ Mineral Sequestration Studies in US. Available online: https://www.netl.doe.gov/publications/proceedings/01/carbon_seq/1b2.pdf (accessed on 01 August 2019).

Cucchiella, F., D’Adamo, I. and Gastaldi, M., 2017. Sustainable waste management: Waste to energy plant as an alternative to landfill. Energy Conversion and Management, 131, pp.18-31. https://doi.org/10.1016/j.enconman.2016.11.012

Nagarjun, Y. and Ganesh, K.L., 2015, December. Field experiences with ageing electrical assets in power plants. In 2015 International Conference on Condition Assessment Techniques in Electrical Systems (CATCON) (pp. 7-12). IEEE. DOI: 10.1109/CATCON.2015.7449499 